\title{
GLYCINOTHRICIN, A NEW STREPTOTHRICIN-CLASS ANTIBIOTIC FROM STREPTOMYCES GRISEUS
}

\author{
Yosuke Sawada, Sadako Kawakami and Hyozo Taniyama \\ Faculty of Pharmaceutical Sciences, Nagasaki University, Nagasaki 852, Japan \\ Kiyoshi Hamano, Ryuzo Enokita, Seigo Iwado and Mamoru Arai \\ Fermentation Research Laboratories, Sankyo Co., Ltd. \\ Hiromachi, Shinagawa-ku, Tokyo 140, Japan \\ (Received for publication February 25, 1977)
}

\begin{abstract}
Glycinothricin is a streptothricin-class antibiotic obtained for the first time from the culture broth of a strain of Streptomyces griseus. Glycinothricin, the deformimino derivative of antibiotic LL-AB664, gives N-methylstreptolidine, N-methyl-D-glucosamine and glycine on acid hydrolysis. In comparison with LL-AB664, glycinothricin is less active against gram-positive and gram-negative bacteria and less toxic to mice.
\end{abstract}

A new streptothricin-class antibiotic, glycinothricin, was obtained from the fermentation broth of a streptomycete, strain No. 979, isolated from a soil sample collected at Noroshi, Ishikawa Pref., Japan. The antibiotic was isolated as an amorphous hydrochloride by the conventional method for isolation of basic water-soluble antibiotics. Glycinothricin is similar in structure to LL-AB6641,2,3), but differs from it by the absence of a formimino group. This is the first time this antibiotic is reported as a fermentation product, though it was presumed to be formed by degradation of antibiotic LL-AB664 ${ }^{4}$.

\section{Taxonomic Studies}

The cultural characteristics of strain No. 979, the producer of glycinothricin were determined by the use of the methods described by Shirling and Gotrlieb ${ }^{5)}$. Observations of the culture were made after incubation at $28^{\circ} \mathrm{C}$ for 2 weeks, except where othewise mentioned. The taxonomic keys of Bergey's Manual (8th ed.), of WAKSMAn in "The Actinomycetes", vol. 2 and of others were used to compare the culture with recognized genera and species of the actinomycetes.

Strain No. 979 was classified as a member of the genus Streptomyces. The aerial hyphae indicated monopodial branching with sporophores of Rectus-Flexibilis. The spores are elliptical in shape, $0.4 \sim 0.6 \times 0.6 \sim 1.2 \mu$ in size and with a smooth surface. The cultural characteristics are summarized in Table 1. On most media the color of the substrate mycelia was dull yellow to yellowish brown and the mass color of the aerial mycelia was brownish white to brownish gray. Physiological properties and utilization of carbon sources are summarized in Tables 2 and 3.

After comparison of these characteristics with those of known species of Streptomyces, S. griseus was selected as being most closely related. Simultaneous cultivation of strain No. 979 and S. griseus IAM 0084 yielded the results described in Tables $1 \sim 3$. Morphological as well as cultural and physiological characteristics of these two strains were in good agreement, although some differences were found as follows: the deep yellow color of the substrate mycelia of strain No. 979 and the contradictory results obtained with the tyrosinase reaction, as well as with the liquefaction of gelatin and the utilization of $i$-inositol, raffinose and salicin. The differences, however, were not sufficient to desig- 
Table 1. Cultural characteristics of strain No. 979 in comparison with Streptomyces griseus IAM 0084

\begin{tabular}{|c|c|c|c|}
\hline Medium & & Strain No. 979 & S. griseus IAM 0084 \\
\hline Sucrose-nitrate agar & $\begin{array}{r}\mathrm{G} \\
\mathrm{AM} \\
\mathrm{R} \\
\mathrm{SP}\end{array}$ & $\begin{array}{l}\text { Abundant } \\
\text { Light brownish white } \\
\text { Dull yellow } \\
\text { None }\end{array}$ & $\begin{array}{l}\text { Poor } \\
\text { Pale yellowish orange } \\
\text { Pale yellow } \\
\text { None }\end{array}$ \\
\hline Glucose-asparagine agar & $\begin{array}{r}\mathrm{G} \\
\mathrm{AM} \\
\mathrm{R} \\
\mathrm{SP}\end{array}$ & $\begin{array}{l}\text { Good } \\
\text { Brownish white } \\
\text { Pale yellowish brown } \\
\text { None }\end{array}$ & $\begin{array}{l}\text { Good } \\
\text { Pale yellowish orange } \\
\text { Pale yellowish orange } \\
\text { None }\end{array}$ \\
\hline $\begin{array}{l}\text { Glycerol-asparagine agar } \\
\text { (ISP 5) }\end{array}$ & $\begin{array}{r}\mathrm{G} \\
\mathrm{AM} \\
\mathrm{R} \\
\mathrm{SP}\end{array}$ & $\begin{array}{l}\text { Good } \\
\text { Brownish white } \\
\text { Dull yellow } \\
\text { None }\end{array}$ & $\begin{array}{l}\text { Good } \\
\text { Pale yellowish orange } \\
\text { Pale yellowish brown } \\
\text { None }\end{array}$ \\
\hline $\begin{array}{l}\text { Inorganic salts-starch agar } \\
\text { (ISP 4) }\end{array}$ & $\begin{array}{r}\mathrm{G} \\
\mathrm{AM} \\
\mathrm{R} \\
\mathrm{SP}\end{array}$ & $\begin{array}{l}\text { Abundant } \\
\text { Grayish white } \\
\text { Pale yellowish brown } \\
\text { None }\end{array}$ & $\begin{array}{l}\text { Good } \\
\text { Brownish white } \\
\text { Grayish yellow brown } \\
\text { None }\end{array}$ \\
\hline $\begin{array}{l}\text { Tyrosine agar } \\
\text { (ISP 7) }\end{array}$ & $\begin{array}{r}\mathrm{G} \\
\mathrm{AM} \\
\mathrm{R} \\
\mathrm{SP}\end{array}$ & $\begin{array}{l}\text { Abundant } \\
\text { Pale brown } \\
\text { Yellowish brown } \\
\text { None }\end{array}$ & $\begin{array}{l}\text { Abundant } \\
\text { Light brownish gray } \\
\text { Dark yellowish brown } \\
\text { Grayish yellow brown }\end{array}$ \\
\hline $\begin{array}{l}\text { Nutrient agar } \\
\text { (Difco) }\end{array}$ & $\begin{array}{r}\mathrm{G} \\
\mathrm{AM} \\
\mathrm{R} \\
\mathrm{SP}\end{array}$ & $\begin{array}{l}\text { Good } \\
\text { Brownish white } \\
\text { Pale yellowish brown } \\
\text { None }\end{array}$ & $\begin{array}{l}\text { Poor } \\
\text { White } \\
\text { Pale yellowish brown } \\
\text { None }\end{array}$ \\
\hline $\begin{array}{l}\text { Yeast extract-malt extract agar } \\
\text { (ISP 2) }\end{array}$ & $\begin{array}{r}\mathrm{G} \\
\mathrm{AM} \\
\mathrm{R} \\
\mathrm{SP}\end{array}$ & $\begin{array}{l}\text { Abundant } \\
\text { Light brownish gray } \\
\text { Dull yellowish orange } \\
\text { None }\end{array}$ & $\begin{array}{l}\text { Abundant } \\
\text { Light brownish gray } \\
\text { Yellowish brown } \\
\text { None }\end{array}$ \\
\hline $\begin{array}{l}\text { Oatmeal agar } \\
\text { (ISP 3) }\end{array}$ & $\begin{array}{r}\mathrm{G} \\
\mathrm{AM} \\
\mathrm{R} \\
\mathrm{SP}\end{array}$ & $\begin{array}{l}\text { Abundant } \\
\text { Pale yellowish orange } \\
\text { Dull yellow } \\
\text { None }\end{array}$ & $\begin{array}{l}\text { Abundant } \\
\text { Pale yellowish orange } \\
\text { Pale yellowish brown } \\
\text { None }\end{array}$ \\
\hline
\end{tabular}

G: Growth, AM: Aerial mycelium, R: Reverse, SP: Soluble pigment.

Table 2. Physiological properties of strain No. 979 in comparison with Streptomyces griseus IAM 0084

\begin{tabular}{l|l|l}
\hline & Strain No. 979 & S. griseus IAM 0084 \\
\hline Tyrosinase reaction & - & + \\
Nitrate reduction & + & + \\
Starch hydrolysis & + (weak) & + (strong) \\
Gelatin liquefaction & + & - \\
Milk coagulation at $26^{\circ} \mathrm{C}$ & + & + \\
at at $37^{\circ} \mathrm{C}$ & + & $\pm(\mathrm{pH} \mathrm{6.2)}$ \\
Milk peptonization at $26^{\circ} \mathrm{C}$ & - & $+($ strong, pH 6.2) \\
"at anoid pigment* & + (strong, pH 7.4) & - \\
\hline
\end{tabular}

* Not produced in peptone-yeast extract-iron agar (ISP 6), tyrosine agar (ISP 7), nor tryptone-yeast extract broth (ISP 1). 
Table 3. Utilization of carbon sources by strain No. 979 and Streptomyces griseus IAM 0084

\begin{tabular}{l|c|c|c|c|c}
\hline & Strain No. 979 & $\begin{array}{c}\text { S. griseus } \\
\text { IAM 0084 }\end{array}$ & & Strain No. 979 & $\begin{array}{c}\text { S. griseus } \\
\text { IAM 0084 }\end{array}$ \\
\hline D-Glucose & + & + & D-Galactose & ++ & + \\
L-Arabinose & - & - & Sucrose & - & - \\
D-Xylose & \pm & + & Raffinose & ++ & - \\
D-Fructose & + & + & D-Mannitol & ++ & + \\
L-Rhamnose & - & - & Salicin & + & - \\
$i$-Inositol & + & - & & & + \\
\hline
\end{tabular}

++ Good growth, + Growth, \pm Scant growth, - No growth.

nate strain No. 979 as a new species. Therefore strain No. 979 was named Streptomyces griseus No. 979.

\section{Fermentation and Isolation}

Glycinothricin was produced by S. griseus No. 979 in a 600-liter fermentor containing 300 liters of medium consisting of $3 \%$ starch, $2 \%$ corn-steep liquor, $1.5 \%$ Pharmamedia, $1 \%$ meat extract and $0.01 \%$ Disfoam CB-442 (pH 7.0 before sterilization). The batch was inoculated with 25 liters of seed culture fermented in a 100-liter fermentor with the identified medium for 27 hours at $27^{\circ} \mathrm{C}$. Fermentation was conducted with agitation $(175 \mathrm{rev} / \mathrm{min})$ and aeration $(300 \mathrm{liters} / \mathrm{min})$ for 47 hours at $27^{\circ} \mathrm{C}$. The antimicrobial activity of the culture broth was estimated by a cylinder-plate method using Escherichia coli NIHJ JC-2 as the test organism. The potency obtained after 27 hours of cultivation was $1,100 \mu \mathrm{g} / \mathrm{ml}$. The culture broth (320 liters) was adjusted to $\mathrm{pH} 4.0$ and filtered with the aid of infusorial earth to remove mycelial cake. The filtrate ( 270 liters) was adjusted to $\mathrm{pH} 8.5$ with $\mathrm{NaOH}$ and adsorbed on activated carbon $(4.35 \mathrm{~kg})$. The carbon cake obtained by filtration was washed with 50 liters of $50 \%$ aqueous acetone $(\mathrm{pH} 8.5$ with $\mathrm{NaOH})$. The adsorbate was eluted twice with a total of 120 liters of $50 \%$ acidic aqueous acetone ( $\mathrm{pH} 4.0$ with $\mathrm{HCl}$ after agitation). The eluate was

Table 4. Physico-chemical properties of glycinothricin (GT) and LL-AB664 hydrochlorides

\begin{tabular}{|c|c|c|}
\hline & GT hydrochloride & LL-AB664 hydrochloride ${ }^{1)}$ \\
\hline m.p. & $182 \sim 185^{\circ} \mathrm{C}$ & $210^{\circ} \mathrm{C}$ \\
\hline \multirow{3}{*}{$\begin{array}{l}\text { Formula (tentative) and } \\
\text { elementary analysis }\end{array}$} & $\mathrm{C}_{17} \mathrm{H}_{29} \mathrm{O}_{8} \mathrm{~N}_{7} 2 \mathrm{HCl} \cdot 2 \mathrm{H}_{2} \mathrm{O}$ & $\mathrm{C}_{18} \mathrm{H}_{30} \mathrm{O}_{8} \mathrm{~N}_{8} 2 \mathrm{HCl} \cdot \mathrm{H}_{2} \mathrm{O}$ \\
\hline & $\begin{array}{r}\text { Anal. Calcd. : C } 35.92, \mathrm{H} 6.21 \text {, } \\
\text { N } 17.25, \mathrm{Cl} 12.47\end{array}$ & $\begin{aligned} \text { Anal. Calcd.: } & \text { C 37.44, H 5.89, } \\
& \text { N } 19.41, \mathrm{Cl} 12.30\end{aligned}$ \\
\hline & $\begin{aligned} \text { Found: } & \text { C } 35.93, \mathrm{H} 6.08 \\
& \mathrm{~N} 17.22, \mathrm{Cl} 13.76\end{aligned}$ & $\begin{aligned} \text { Found: } \mathrm{C} 37.24, \mathrm{H} 6.33 \\
\text { N } 18.19, \mathrm{Cl} 11.07\end{aligned}$ \\
\hline $\mathrm{pKa}^{\prime}$ & $7.1, \quad 9.5$ & $7.1, \quad 9.2$ \\
\hline Optical rotation & {$[\alpha]_{\mathrm{D}}^{22}-69.1\left(c 1, \mathrm{H}_{2} \mathrm{O}\right)$} & {$[\alpha]_{\mathrm{D}}^{22}-62.2\left(c 1, \mathrm{H}_{2} \mathrm{O}\right)$} \\
\hline Ultraviolet absorption & \multicolumn{2}{|c|}{ no characteristic bands in water and acidic or alkaline water } \\
\hline $\begin{array}{l}\text { NMR (in } \mathrm{D}_{2} \mathrm{O} \text { ) ppm } \\
\text { from } \mathrm{DSS}^{2} \text { ) }\end{array}$ & $\begin{array}{l}2.94(\mathrm{~s}, 3 \mathrm{H}), 3.03(\mathrm{~s}, 3 \mathrm{H}) \\
5.46(\mathrm{~d}, 1 \mathrm{H}, \mathrm{J}=8 \mathrm{~Hz})\end{array}$ & $\begin{array}{l}2.84(\mathrm{~s}, 3 \mathrm{H}), 3.02(\mathrm{~s}, 3 \mathrm{H}) \\
5.52(\mathrm{~d}, 1 \mathrm{H}, \mathrm{J}=8 \mathrm{~Hz}) \\
7.96(\mathrm{~s}, 1 \mathrm{H})\end{array}$ \\
\hline Stability & \multicolumn{2}{|c|}{ stable at neutral $\mathrm{pH}$, unstable at alkaline $\mathrm{pH}$} \\
\hline Solubility & \multicolumn{2}{|c|}{$\begin{array}{l}\text { soluble in } \mathrm{H}_{2} \mathrm{O}, \mathrm{MeOH} \text { and } \\
\text { slightly soluble in EtOH, pyridine, acetic acid, DMF and DMSO }\end{array}$} \\
\hline
\end{tabular}

1) Sample O-837-A.

2) The NMR spectra were recorded with Nihondenshi JNM-PS-100 Spectrometer. 
concentrated in vacuo to give 4 liters of the solution containing $83.5 \mathrm{~g}$ of glycinothricin in $29.0 \%$ recovery from the culture filtrate.

A 400-ml aliquot of the concentrate was adjusted to $\mathrm{pH} 7.0$ with dil. $\mathrm{NaOH}$ and treated with 10 parts of acetone. The precipitate formed was dissolved in water, collected by centrifugation, adsorbed on a column $(4 \times 56 \mathrm{~cm})$ of CM-Sephadex C-25 equilibrated with $0.1 \mathrm{M}$ ammonium formate. Glycinothricin was eluted from the column with $0.4 \mathrm{M}$ and $0.6 \mathrm{M}$ ammonium formate, successively. Active fractions $(370 \mathrm{ml})$ were pooled and concentrated to $30 \mathrm{ml}$ in vacuo. The concentrate was passed through a column $(4 \times 5.5 \mathrm{~cm})$ of activated carbon, which was washed with water and developed with $50 \%$ aqueous acetone $(\mathrm{pH} 2.0)$. Active fractions were concentrated and purified on a column $(2.8 \times 140 \mathrm{~cm})$ of Sephadex LH-20, using water as an eluant. The eluate was monitored by ninhydrin reaction on a paper chromatogram using Toyo-Roshi No. $51 \mathrm{UH}$ paper and a solvent system of $\mathrm{BuOH}$-pyridine- $\mathrm{AcOH}-\mathrm{H}_{2} \mathrm{O}-t-\mathrm{BuOH}(15: 10: 3: 12: 4, \mathrm{v} / \mathrm{v})$. The eluate fractions containing glycinothricin were collected and concentrated in vacuo. The crude powder of the hydrochloride salt was obtained by addition of $0.3 \mathrm{~N} \mathrm{HCl}$ and 10 parts of acetone to the concentrate. Further purification was performed by column chromatography on Sephadex LH-20 using water as an eluant. The purified glycinothricin was detected as a clear single spot with reagents, such as ninhydrin and RYDON-SMITH, on a paper chromatogram. It was lyophilized to give a powder in yield of $1.5 \mathrm{~g}$.

To show that glycinothricin is not an artifact of isolation arising from loss of a formimino group from a fermentation product, the concentrated solution of the culture filtrate (1 liter) was directly introduced onto the column $(2.8 \times 140 \mathrm{~cm})$ of Sephadex LH-20 and developed with water. Fractions having activity against $E$. coli were pooled and concentrated in vacuo. After repetition of this procedure three times followed by lyophilization, about $200 \mathrm{mg}$ of glycinothricin free base was obtained.

\section{Physico-chemical Properties}

Glycinothricin hydrochloride is a white amorphous powder of m.p. $182 \sim 185^{\circ} \mathrm{C}$. Comparison of physico-chemical properties with those of LL-AB664 (sample O-837-A) are summarized in Table 4. The IR spectrum of glycinothricin measured in $\mathrm{KBr}$ tablet is given in Fig. 1. The NMR spectrum of the antibiotic in $\mathrm{D}_{2} \mathrm{O}$ is indicated in Fig. 2. The titration curve from which $\mathrm{pKa}^{\prime}$ values were obtained

Fig. 1. IR Spectrum of glycinothricin hydrochloride in $\mathrm{KBr}$

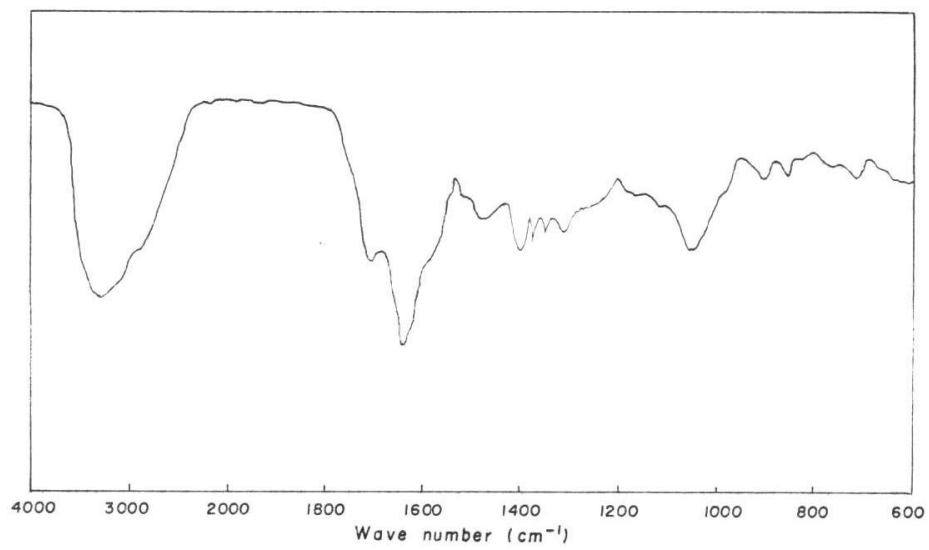


Fig. 2. NMR Spectrum of glycinothricin hydrochloride in $\mathrm{D}_{2} \mathrm{O}$.

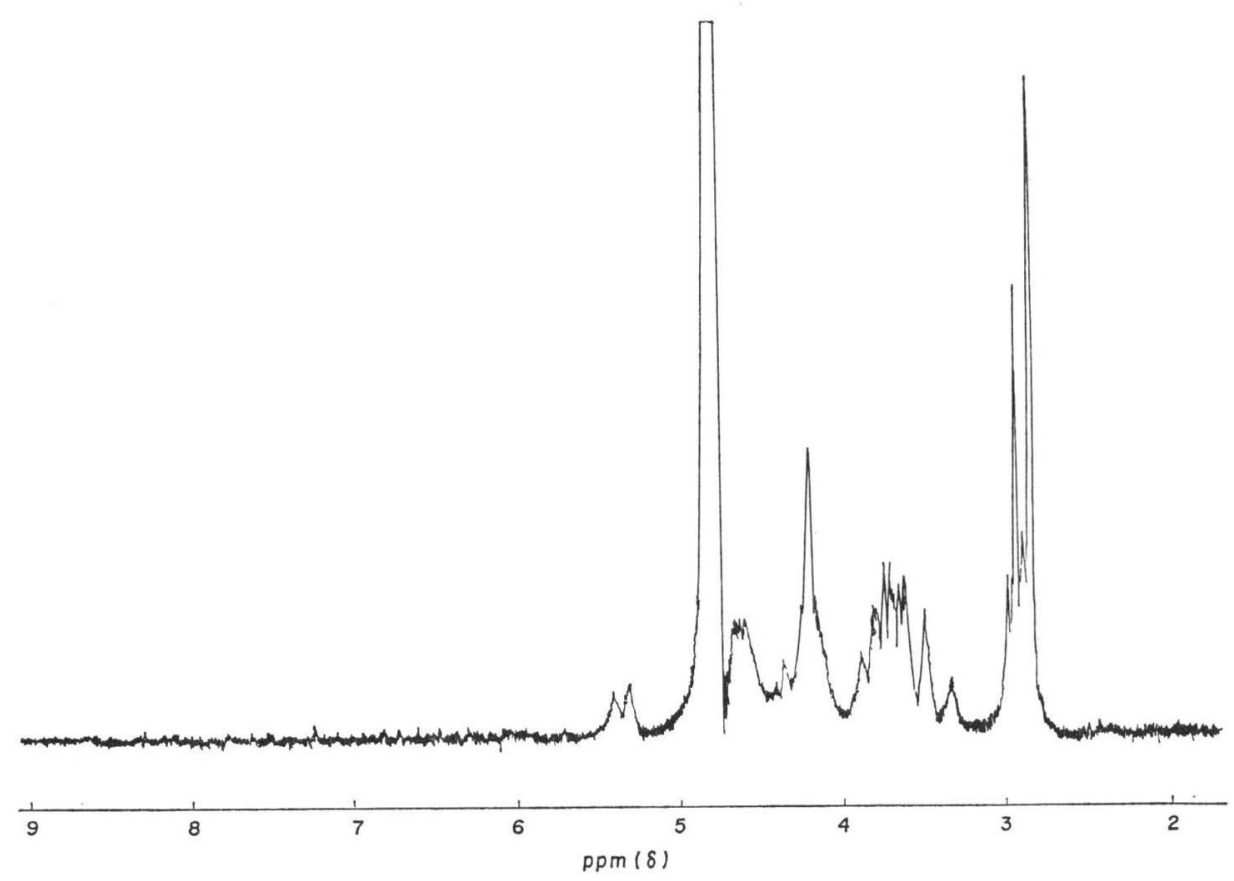

Table 5. Chromatographic and electrophoretic comparison of glycinothricin with other streptothricins

\begin{tabular}{|c|c|c|c|c|c|c|}
\hline \multirow{2}{*}{ Antibiotic } & \multicolumn{2}{|c|}{$\operatorname{PPC}(\mathrm{Rf})^{1)}$} & \multicolumn{2}{|c|}{ TLC(Rf $)^{2)}$} & \multicolumn{2}{|c|}{$\operatorname{PEP}(\mathrm{cm})^{3)}$} \\
\hline & I & II & I & II & III & IV \\
\hline Glycinothricin & 0.53 & 0.49 & 0.34 & 0.28 & 7.0 & 12.0 \\
\hline LL-AB664 & 0.54 & 0.49 & 0.33 & 0.27 & 7.0 & 12.0 \\
\hline Citromycin & 0.44 & 0.38 & 0.22 & 0.14 & 6.8 & 12.2 \\
\hline SF-701 & 0.46 & 0.45 & 0.19 & 0.26 & 6.5 & 10.9 \\
\hline Racemomycin A & 0.35 & 0.24 & 0.16 & 0.14 & 8.0 & 13.4 \\
\hline
\end{tabular}

1) Paper chromatography, Toyo-Roshi No. $51 \mathrm{UH}$.

2) Thin-layer chromatography, Avicel SF (Funakoshi Co.)

8) Paper electrophoresis, Toyo-Roshi No. 51, moved toward cathode.

Solvent systems:

I: $\mathrm{BuOH}-$ pyridine - $\mathrm{AcOH}-\mathrm{H}_{2} \mathrm{O}-t-\mathrm{BuOH}(15: 10: 3: 12: 4)$

II: $\mathrm{BuOH}-\mathrm{AcOH}-\mathrm{H}_{2} \mathrm{O}(4: 1: 2)$

III: Pyridine - $\mathrm{AcOH}-\mathrm{H}_{2} \mathrm{O}(36: 4: 964)$, pH 6.14, 7 V/cm, 2 hours.

IV: Pyridine - $\mathrm{AcOH}-\mathrm{H}_{2} \mathrm{O}(6: 20: 974), \mathrm{pH} 3.85,12 \mathrm{~V} / \mathrm{cm}, 2$ hours. suggested that it is a dibasic compound. It was positive for ninhydrin (yellow to purple), Pauly (green), Elson-Morgan, $\mathrm{KMnO}_{4}$, triphenyltetrazolium, while it was negative for SAKAGUCHI. It gave doubtful reactions to biuret, FeHLING and Tollens. Paper and thin-layer chromatographic and electrophoretic comparisons of glycinothricin with other streptothricin-class antibiotics are shown in Table 5. Glycinothricin was found to have properties similar to the three samples of LLAB664 (LL-AB664, BD-12 and O837-A). However, glycinothricin was distinguished from LL-AB664 by the NMR spectrum, in which absence of an amidino proton for glycinothricin was indicated, and by the elemental analyses (Table 4).

\section{Degradation Studies}

Acid hydrolysis of glycinothricin was carried out in $6 \mathrm{~N} \mathrm{HCl}$ at $120^{\circ} \mathrm{C}$ for 20 hours in a sealed tube. On amino-acid analysis (Hitachi KLA-3 type, $\mathrm{pH} 5.28,50^{\circ} \mathrm{C}$ ) of the hydrolysate, glycine and 
ammonia in $1: 1$ ratio and lesser amounts of methylamine were detected, but no streptolidine.

Glycinothricin base $(50 \mathrm{mg})$ was dissolved in water $(9 \mathrm{ml})$, a saturated aqueous solution of barium hydroxide $(6 \mathrm{ml})$ was added and the resulting mixture was kept at room temperature for 2 days. The precipitate of barium carbonate ob-

Chart 1

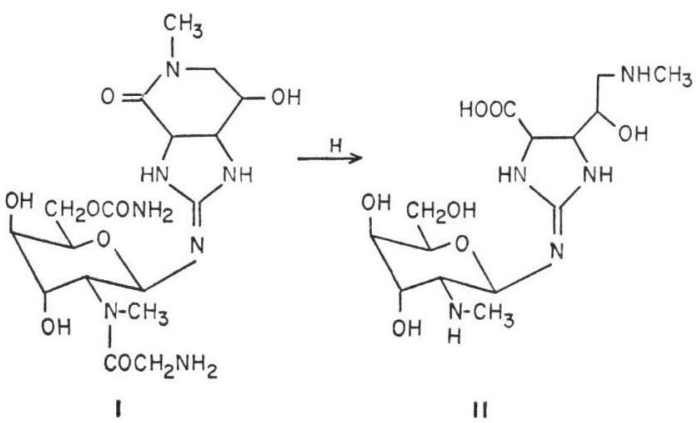

Fig. 3. Comparative TLC of partial hydrolysis products from racemomycin A (RM-A), glycino thricin (GT), citromycin (CiM) and SF-701

TLC (Avicel SF)

Solvent: $\mathrm{PrOH}$ - pyridine - $\mathrm{AcOH}$ $\mathrm{H}_{2} \mathrm{O}(15: 10: 3: 12)$

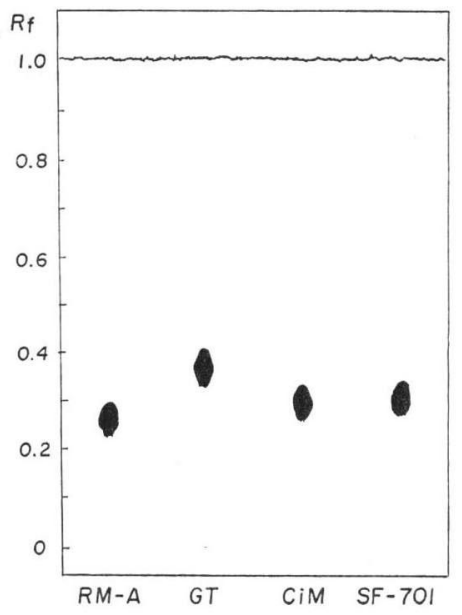

tained was $18 \mathrm{mg}$ in dry weight $(0.85 \mathrm{~mol})$. Moreover, IR spectrum of the antibiotic showed a carbamoyl-carbonyl band at $1710 \mathrm{~cm}^{-1}$ as shown in Fig. 1 . These results suggested the presence of a carbamoyl group in the molecule of glycinothricin.

Milder hydrolysis $\left(4 \mathrm{~N} \mathrm{HCl}, 110^{\circ} \mathrm{C}, 24\right.$ hours $)$ of the antibiotic $(100 \mathrm{mg})$ was also carried out to establish further structural features. The hydrolysate was applied onto a column $(2 \times 40 \mathrm{~cm})$ of CMSephadex C-50, equilibrated with $0.1 \mathrm{M}$ pyridine-acetate buffer, $\mathrm{pH} 6.3$, and eluted with $0.1 \mathrm{M}(300 \mathrm{ml})$, $0.3 \mathrm{M}(100 \mathrm{ml})$ and $1.0 \mathrm{M}$ buffer of the same components stepwisely and fractionated into $5 \mathrm{ml}$ per tube. Fractions containing the three different constituents were collected respectively. Fractions $18 \sim$ 28, positive for ninhydrin and with Rf 0.24 on a paper chromatogram (conditions were the same as described in Table 4) gave glycine (20 mg), fractions 80 100, positive for ELSON-MorGaN and triphenyltetrazolium and with Rf 0.54, were thought to contain an amino sugar (10 mg) and fractions 195 285, positive for ninhydrin, Elson-Morgan and RYDon-SMItH and with Rf 0.36, seemed to give N-guan$\mathrm{N}^{\prime}$-methylstreptolidyl-N"'-methyl- $\alpha$-D-gulosaminide. Fractions $195 \sim 285$ were pooled, concentrated to a small volume and introduced onto a column $(2.8 \times 150 \mathrm{~cm})$ of Sephadex LH-20. The column was washed with water and a RYDON-SMITH positive effluent was collected and concentrated to dryness in vacuo in yield of about $50 \mathrm{mg}$ of the powder. The compound was converted to the hydrochloride salt by addition of dil. $\mathrm{HCl}$ and acetone; m.p. $200^{\circ} \mathrm{C}$ with decomposition.

Anal. Calcd. for $\mathrm{C}_{14} \mathrm{H}_{27} \mathrm{O}_{7} \mathrm{~N}_{5} \cdot 3 \mathrm{HCl} \cdot 2 \mathrm{H}_{2} \mathrm{O}$ : C $32.16, \mathrm{H} 6.56, \mathrm{~N} 13.40$. Found:

C $33.66, \mathrm{H} 6.52, \mathrm{~N} 13.76$.

The NMR spectrum of this compound was similar to that of the same hydrolysis product ${ }^{6)}$ obtained from citromycin ${ }^{\text {) }}$ (sample E-749-C ${ }^{8)}$ ) and SF-701 ${ }^{9}$. In contrast to citromycin, however, two $\mathrm{N}$-methyl absorptions $(\delta=2.70,2.78)$ were still present, while a signal at $\delta=4.33,2 \mathrm{H}$ for a methylene proton of glycine, was absent in the case of glycinothricin. An absorption of an anomeric proton $(\delta=5.54, \mathrm{~d}, \mathrm{~J}=7.5 \mathrm{~Hz})$ suggested that the configuration at $\mathrm{C}-1$ on the amino sugar is retained as it is 
in the parent antibiotic under hydrolysis and the following separation procedure. The IR spectrum of the hydrochloride salt of the compound indicated the presence of a carboxyl group (1735 $\mathrm{cm}^{-1}$ ) but the absence of carbamoyl group. The compound, therefore, could be distinguished readily from the related compounds derived from the partial hydrolysates of racemomycin $\mathrm{A}^{10)}$, citromycin and SF-701 as shown in Fig. 3. These results supported that the structure of this hydrolysis product of glycinothricin is $\mathrm{N}$ guan- $\mathrm{N}^{\prime}$ - methyl-streptolidyl-N"'-methyl- $\alpha$-D-gulosaminide (Structure II in Chart 1).

\section{Biological Properties}

Antimicrobial activities of glycinothricin and LL-AB664 (sample O-837-A) by agar dilution method are summarized in Table 6. As evident from the results, glycinothricin possessed weaker antimicrobial activities than did LLAB664 (sample O-837-A). Cross resistance with racemomycin A and citromycin was also observed with both antibiotics.

Glycinothricin hydrochloride was administered to mice (RFVL strain, $20 \mathrm{~g}$ weight, 5 animals in a group) intravenously to determine its toxicity. The $\mathrm{LD}_{50}$ was $100 \sim 200 \mathrm{mg} / \mathrm{kg}$, while that of LL-AB664 (sample O-837-A) was $50 \sim 100 \mathrm{mg} / \mathrm{kg}$, evaluated two weeks after injection. Necrotic symptoms characteristic to streptothricin-class antibiotics were observed on the tails of mice at the site of injection.

\section{Discussion}

When glycinothricin was directly compared with known streptothricin antibiotics using paper and thin-layer chromatographic procedures and paper electrophoresis, close resemblance of glycinothricin to LL-AB664 was observed (Table 5).

Glycine, instead of $\beta$-lysine, was found in the hydrolysate of glycinothricin. N-guan.-N'-Methylstreptolidyl- $\mathrm{N}^{\prime \prime}$-methyl- $\alpha$-D-gulosaminide was obtained by mild acid-hydrolysis of glycinothricin as with LL-AB664. However, absence of the formimino group in glycinothricin based on its NMR spectrum and its elemental analysis indicated that glycinothricin is the deformimino derivative of LL-AB664 (Structure I in Chart I).

Streptomyces hygroscopicus NRRL 3111 has been reported to produce antibiotic LL-AC541 together with its deformimino derivative in its culture broth ${ }^{11)}$, but producers of LL-AB664 have not been reported to produce the deformimino derivative of that antibiotic. Ammonium formate was primarily used for the purification of glycinothricin and initially elimination of the formimino group was suspected as being related to this isolation procedure. However, partial purification of the anti- 
biotic from the culture broth of S. griseus No. 979 directly on Sephadex LH-20 and confirmation of the absence of the peak corresponding to the formimino proton in the NMR spectrum proved the presence of native deformimino antibiotic. For purification of LL-AB664 ${ }^{12}$ and sclerothricin ${ }^{12}, \mathrm{NH}_{4} \mathrm{OH}$ was used for the elution of these antibiotics from cation-exchange resin without eliminating the formimino group. This gives further support for the presence of glycinothricin in the culture broth.

The difference in antibacterial activity between glycinothricin and its formimino derivative, LLAB664 reveals that the presence of the formimino group may enhance antimicrobial activity. The greater toxicity of LL-AB664 could also be attributed to the presence of the formimino group.

Production of a streptothricin-class antibiotic by $S$. griseus has been reported by HaLl and BENEDICT $^{13)}$, but comparison of this antibiotic with glycinothricin is not possible because of lack of a detailed description of the physico-chemical properties of the former.

\section{Acknowledgements}

The authors wish to express their thanks to Dr. E. L. PAtTerson, Lederle Laboratories, a Division of American Cyanamide Co., for his supply of LL-AB664 and LL-AC541, to Dr. J. SHost, Shionogi Research Laboratory, Shionogi Co., Ltd., for O-837-A and E-749-C, to Dr. Y. Iто, Microbial Chemistry Research Laboratory, Tanabe Seiyaku Co., Ltd., for BD-12 and BY-81 and to Dr. T. NIIDA, Research Laboratory of Meiji Seika Co., Ltd., for SF-701.

\section{References}

1) Sax, K. J.; P. Monnikendam, D. B. Borders, P. Shu, L. A. Mitscher, W. K. Hausmann \& E. L. PatterSON: LL-AB664, a new streptothricin-like antibiotic. Antimicr. Agents \& Chemoth. -1967: 442 448, 1968

2) Ito, Y.; Y. Ōhashi, Y. Sakurai, M. Sakurazawa, H. Yoshida, S. Awataguchi \& T. Okuda: New basic water-soluble antibiotics BD-12 and BY-81. II. Isolation, purification and properties. J. Antibiotics 21: $307 \sim 313,1968$

3) Sawada, Y.; H. Taniyama, T. Kitagawa \& J. ShojI: unpublished data, a strain of Streptomyces sp. O-837 produced two antibiotics O-837-A (identical with LL-AB664) and O-837-B (identical with LL-AC 541).

4) Borders, D. B.; K. J. Sax, J. E. Lancaster, W. K. Hausmann, L. A. Mitscher, E. R. Wetzel \& E. L. PATTERSON: Structures of LL-AC541 and LL-AB664, new streptothricin-type antibiotics. Tetrahedron 26: $3123 \sim 3133,1970$

5) Shirling, E. B. \& D. Gottlieb: Methods for characterization of Streptomyces species. Internat. J. System. Bacteriol. 16: 313 340, 1966

6) Taniyama, H. \& Y. Sawada: Studies on chromophore groups of streptothricin group antibiotics by optical rotatory dispersion and circular dichroism. Chem. Pharm. Bull. (Tokyo) 20: 596 600, 1972

7) TaniYama, H. \& Y. Sawada: The identity of citromycin with LL-AC541, E-749-C and BY-81. J. Antibiotics 24: 708 710, 1971

8) Shou, J.; S. Kozuki, M. Ebata \& H. Otsuka: A water-soluble basic antibiotic E-749-C identical with LL-AC541. J. Antibiotics 21: 509 511, 1968

9) Tsuruoka, T.; T. Shoumura, N. Ezaki, T. Niwa \& T. NiIda: SF-701, a new streptothricin-like antibiotic. J. Antibiotics 21: 237 238, 1968

10) Taniyama, H.; Y. Sawada \& T. Kitagawa: Characterization of racemomycins. Chem. Pharm. Bull. (Tokyo) 19: 1627 1634, 1971

11) Zbinousky, V.; W. K. Hausmann, E. R. Wetzel, D. B. Borders \& E. L. Patterson: Isolation and characterization of antibiotic LL-AC541. Appl. Microbiol. 16: 614 616, 1968

12) Kōno, Y.; S. Makıno, S. Takeuchi \& H. Yonehara: Sclerothricin, a new basic antibiotic. J. Antibiotics 22: 583 589, 1969

13) Hall, H. H. \& R. G. Benedict: U.S. Patent 2,846,310, August 5, 1958 